\title{
Regional Imbalances in Institutional Credit with Special Reference to Agriculture Loan Segment in India.
}

Mr. Ravishankar L, Research Scholar, Bangalore University, Bengaluru

Dr. Y. Nagaraju, Professor, Canara Bank School of Management Studies, Bangalore University, Bengaluru

\begin{abstract}
:
Credit growth in agriculture in India has been evolving over a period of time, mainly aided by a push from the government. Such lending has led to an increase in yield of farmers and provided them with muchneeded cash to grow crops.

The agricultural development crisis reflected in reduced overall growth accompanied by declining productivity and profitability which has accentuated the general adversity in the livelihoods of small and marginal farmers; the root cause lies in high dependence of the population on agriculture and increasing marginalisation of land holdings. The subject becomes very relevant while dealing with agricultural credit as it forms the backdrop for answering very many demand-side questions.

The objective of the study is to make a systematic analysis of the evolution, trends and composition of institutional credit extended to the agricultural sector in India and the nature of inter-regional, inter-state and intra-state disparities prevailing in the distribution of farm credit.
\end{abstract}

Keywords: Regional Imbalance, Institution Credit, Agriculture Sector in India.

\section{Introduction}

Agriculture provides employment to about 48.9 per cent of the total workforce in India, but contributes only 15.2 per cent to the country's Gross Value Added (GVA). About 85 per cent of operational land holdings in the country are in the small and marginal categories, and the average size of an operational land holding is only 1.15 ha.
However, past performance of the agriculture sector in terms of growth indicated that the sectorial growth has been fluctuating across the periods. For example: The beginning of economic reforms in 1991, the GDP growth in agriculture sector has been highly volatile.

It has been proved from various studies that increase in the supply of agriculture credit lead to increase in the food production in the country. Eg: Green revolution, where the financial institutions played a major role by increasing lending to agriculture sector.

Various stages of agriculture lending in India through Financial Institutions

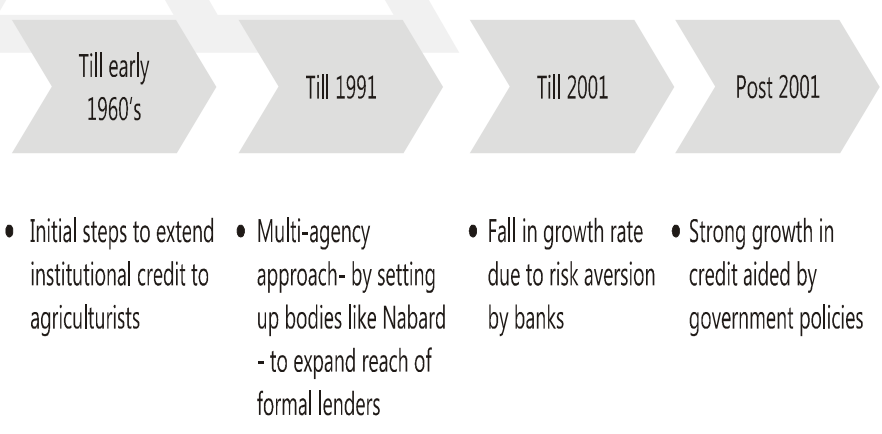

Stage 1: Initial stage of building foundation for agriculture lending prior to 1960

Reserve Bank of India started its operations on April 1, 1935 and has since played a pivotal role in structuring the financial institutions and agriculture cooperatives. The major hindrances during this era was lack of sufficient funds for financing and strong infrastructure. Farmers were deprived of timely access to credit. 
A committee was formed to study the access of institutional credit to farmers and also conducted the All India Rural Credit Survey in 1954 (under the purview of RBI). The outcome of the survey paved the way for a wider role for commercial banks.

Stage 2: Growth stage for Institutional lending to agriculture sector from 1960 to 1990

Nationalisation of banks and introduction of priority sector lending norms in 1969, played pivotal role in harnessing the role of commercial banks

- Understanding the requirement of credit for sensitive sectors of the economy it was allocated certain portion of net bank credit to these sectors.

- Formation of Regional Rural Banks (RRBs) \& Setting up of National Bank for Agriculture and Rural Development (NABARD) - an apex body for policy formulation and refinancing of agricultural credit

Stage 3: Maturity - Risk aversion leads to slower growth from 1990 till 2000-01

Post liberalisation in 1991, health of the financial system and status of rural and agri credit were reassessed on several occasions. While these assessments recognised the significant progress in expanding the network of financial institutions, the overall agricultural credit system was still characterised by low efficiency, rising delinquencies and low profitability. Consequently, many committees were formed through the 1990s to identify means to enhance efficiencies, apart from further widening the reach of formal lenders.

\section{Stage 4: Post 2000-01}

The subsequent decade, however, witnessed the fastest growth in credit offtake, mainly led by scheduled commercial banks.

In June 2004, the central government announced a slew of measures with an aim to double agri-credit over three years to Scheduled Commercial Banks, with a $30 \%$ growth in 2004-05, the credit offtake witnessed fastest growth. Some measures taken by institutes such as Government, RBI, NABARD and Indian Bank Association helped in maintaining the growth.

i) Interest Subvention Scheme

ii) Agriculture Debt waiver and Debt Relief Scheme, 2008

iii) Financial inclusion program

Major Categories of Agriculture Financing

\begin{tabular}{|c|c|}
\hline $\begin{array}{l}\text { Pre-harvest } \\
\text { financing }\end{array}$ & $\begin{array}{l}\text { - Short term loans for production of crops } \\
\text { - Includes loans for seeds, fertiliser, labour, plantation } \\
\text { and horticulture, etc. } \\
\text { - Tenure is one crop season }\end{array}$ \\
\hline $\begin{array}{c}\text { Infrastructure } \\
\text { financing }\end{array}$ & $\begin{array}{l}\text { - Short term or long term loans } \\
\text { - Includes loans for farm mechanisation, land } \\
\text { devolopment, warehouse devolopment and } \\
\text { evolopment of water resources } \\
\text { - Tenure os one crop season to } 18 \text { months }\end{array}$ \\
\hline $\begin{array}{l}\text { Post harvest } \\
\text { financing }\end{array}$ & $\begin{array}{l}\text { - Short term or long term loans } \\
\text { - Includes credit for warehouse recipet and food and } \\
\text { agro processing units } \\
\text { - Tenure is one crop season to } 18 \text { months }\end{array}$ \\
\hline $\begin{array}{l}\text { Allied activities } \\
\text { financing }\end{array}$ & $\begin{array}{l}\text { - Short term loans } \\
\text { - Loans towards animal husbandry, poultry, sheep } \\
\text { rearing, dairy, etc. }\end{array}$ \\
\hline
\end{tabular}

\section{Literature Review}

EPW Research Foundation (2007-08): The report examined the indebtedness of farmer households based on the nationwide surveys of National Sample Survey Organisation, reviewed size and nature of farmer indebtedness state wise and interstate disparity among farmer households.

RP Misra, KV Sundaram, R Prakasa (1974): examined that the Indicators of Disparities have confirmed that the national economy of India is seriously entangled into the cobweb of inter-State and intra-State disparities. These disparities are the direct offshoot of our neglect of spatial factors and lack of genuine regional planning. Since a sound regional economy makes a sound national economy, therefore, there is a pressing need for some pragmatic approach to combat the problem of regional disparities. 
DR.S.Gandhimathi,

\section{DR.P.AMBIGADEVI}

\& V.SHOBANA (2012) has examined that southern region had dominated the other regions of the country. The disparity is higher for the agricultural loan accounts than the agriculture credit. The states with higher state domestic product had greater amount of agriculture credit distribution.

\section{Objectives of the Study:}

i) To study the regional imbalance with reference to the overall institutional credit flow to agriculture.

ii) To study the agriculture NPAs across the states.

iii) To study the agriculture NPAs in small \& marginal farmers across the states.

\section{Analysis \& Interpretation}

Agriculture credit has grown at to reach an estimated Rs 8.8 trillion in 2015-16. For 2016-17, expectation of good monsoons has led to an overall improvement in sentiment. In addition, the Ministry of Agriculture has also increased food grain production goal to a record 272 million tonnes from 252.2 million tonnes in the third advance estimate of 2015-16.

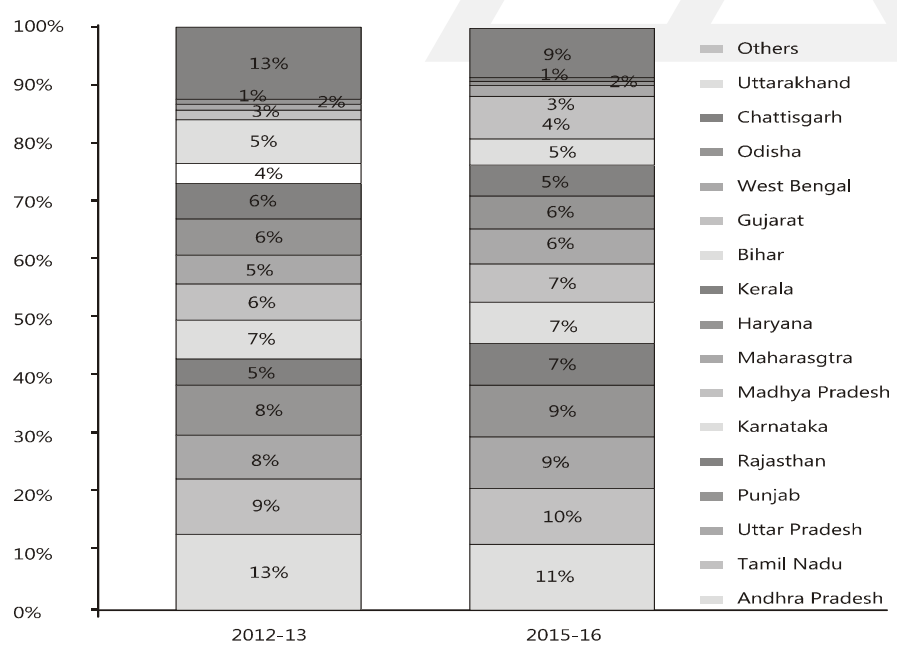

Note: Andhra Pradesh includes credit of Telangana

The bulk of credit disbursed for agriculture purpose is absorbed by 7 states namely Andhra Pradesh \& Telangana, Tamil Nadu, Uttar Pradesh, Punjab and Rajasthan and Karnataka. However the overall share has changed over last few years due to strong growth seen in some states and weaker growth rate seen in others

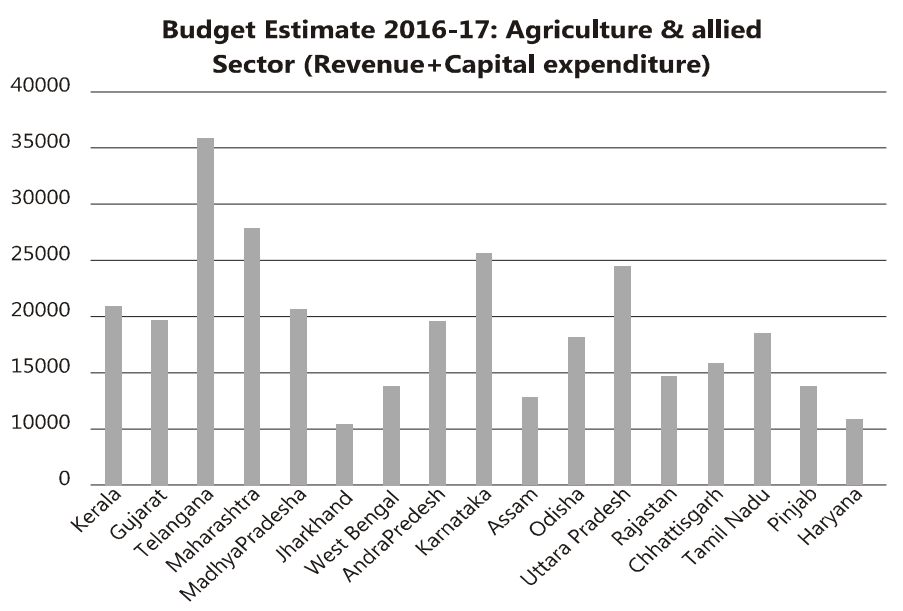

Share (\%) of Capital Expenditure to Budget estimate for Agriculture \& allied sector 2016-17

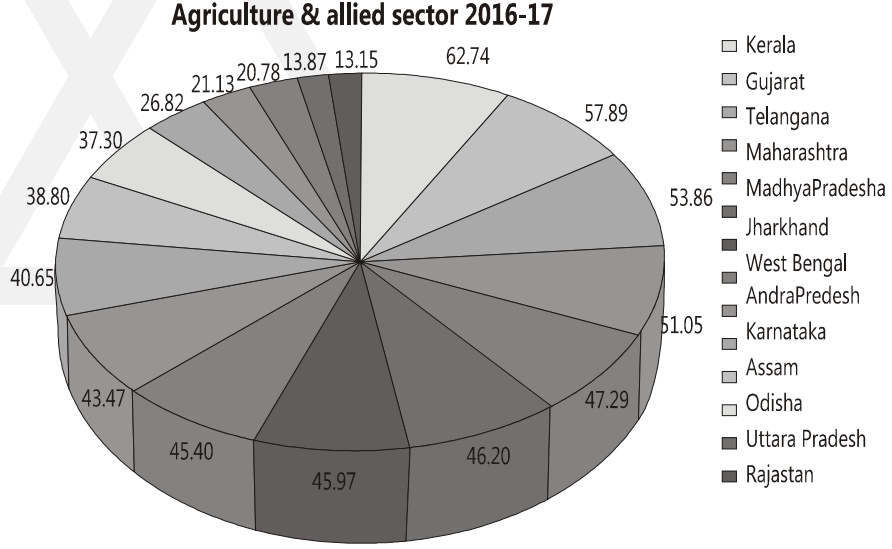

Considering the importance of agriculture and allied sector in increasing income and employment, and also achieving inclusive growth, it is imperative to increase investment in the sector. Hence, budgetary allocations for capital expenditure in agriculture and allied sector need to be increased by states. Budgetary estimates (2016-17) for capital expenditure in agriculture and allied sector in respect of select states are presented. The major states in terms of share of budgetary estimates for capital expenditure on agriculture and allied sector in the total budget for the sector are Kerala, Gujarat, Telangana, 
Maharashtra, Madhya Pradesh, Jharkhand, West

Bengal, Andhra Pradesh, Karnataka and Assam.

GSDP - Agriculture at factor cost (Base 2004-05) (Rs in crore) 2014-15
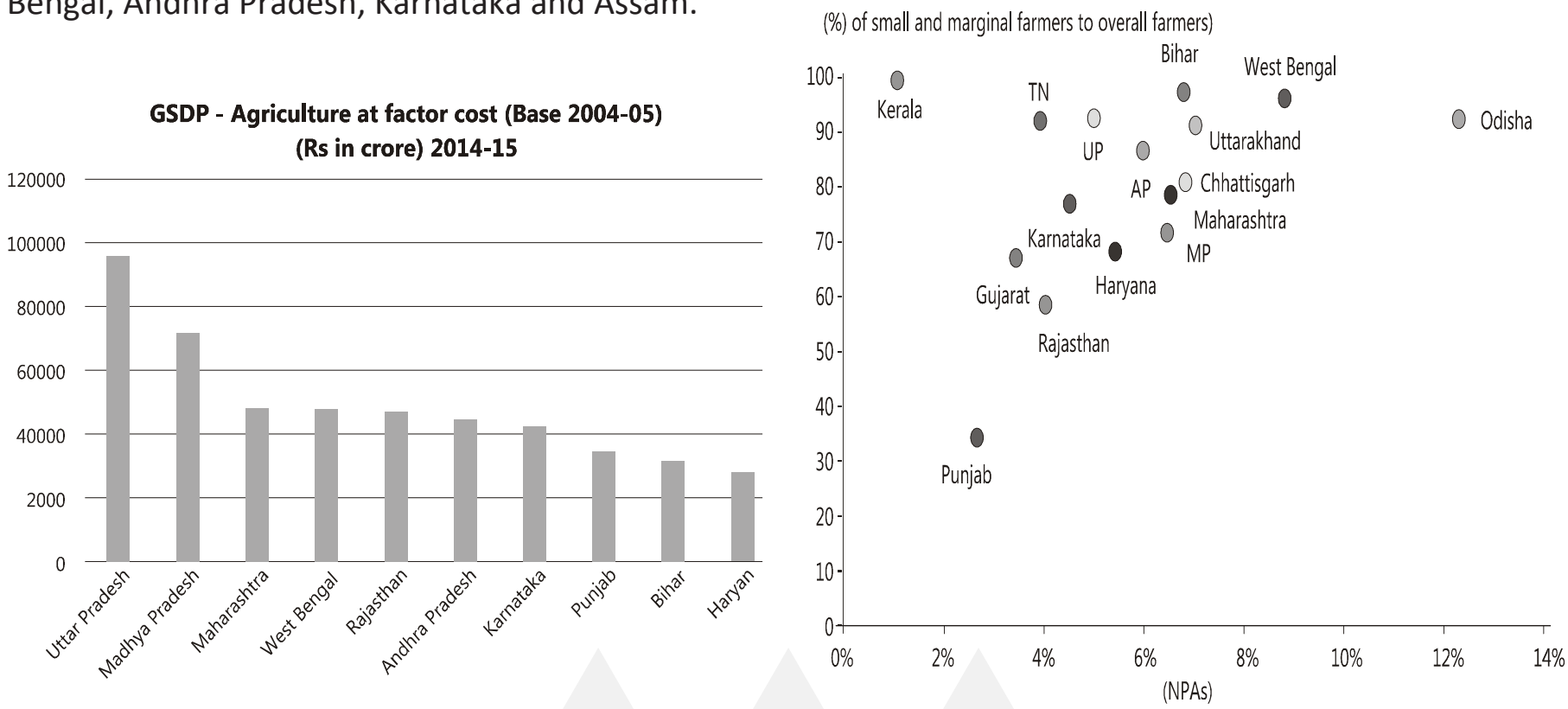

\section{CAGR (\%) of GSDP - Agriculture at constant prices} 2010-11 to 2014-15

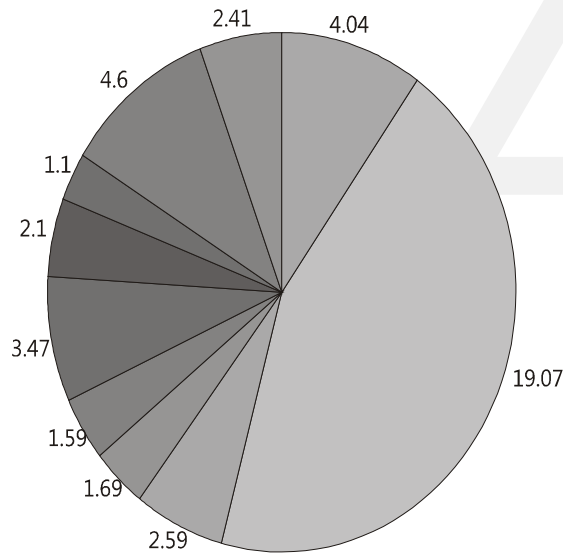

$$
\begin{aligned}
& \square \text { Uttar Pradesh } \\
& \square \text { Madhya Pradesh } \\
& \square \text { Maharashtra } \\
& \square \text { West Bengal } \\
& \square \text { Rajasthan } \\
& \square \text { Andhra Pradesh } \\
& \square \text { Karnataka } \\
& \square \text { Punjab } \\
& \square \text { Bihar } \\
& \square \text { Haryan }
\end{aligned}
$$

Inter-state disparities in agriculture are the reality with some states growing faster. Table gives growth rates and GSDP for 10 major states.

States with higher proportion of marginal farmers (more than 90\%) such as Odisha, Chhattisgarh and West Bengal recorded NPAs above 8\% as of 2014-15. Kerala is an exception with NPAs lower than 2-3\%, despite high proportion of marginal farmers; this is due to high foreign fund flow in the state (from NRIs) and household farming by many families.

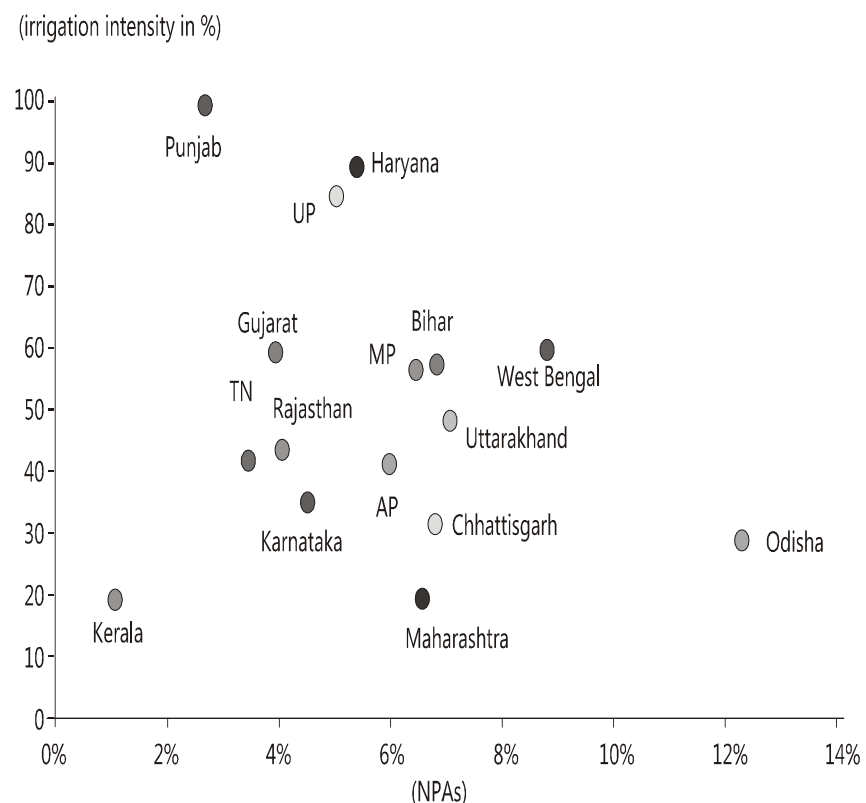


A state with higher irrigation intensity has ability to survive a bad monsoon. An exception to above is again a state like Kerela which receives multiple monsoons in a year and higher proportion of cash crop to overall cultivated area which leads to lower NPAs.

(Credit per hectare in RS./hectare)

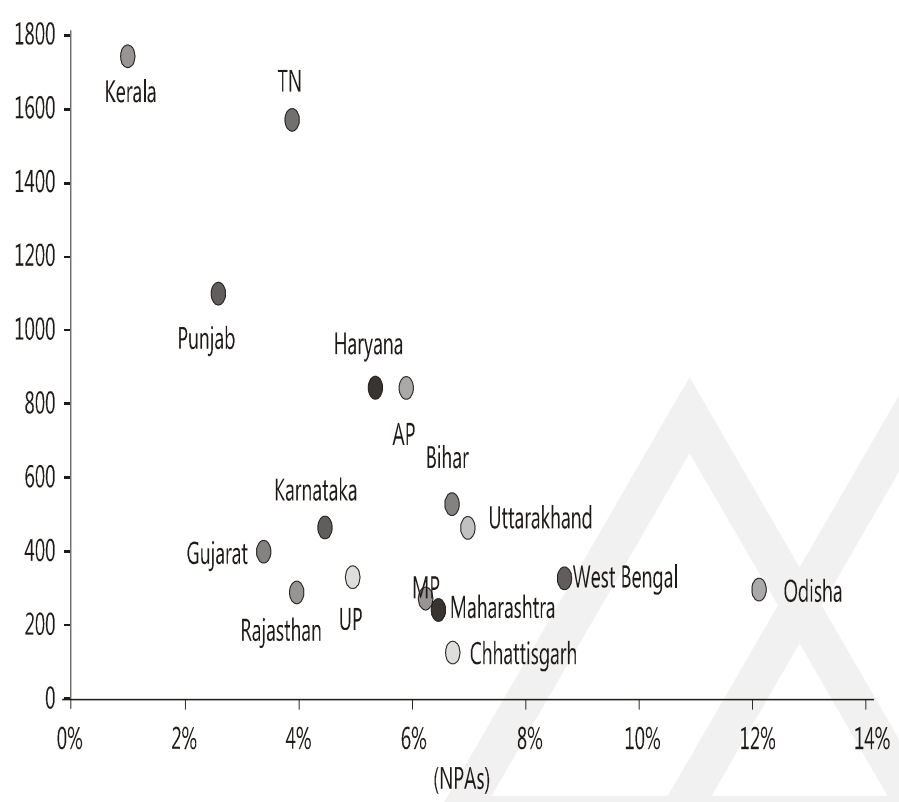

Thus, strong irrigation intensity and lower proportion of marginal farmers in various states lead to lower GNPAs and higher credit disbursal per hectare.

Conclusion: The share and credit growth of the agriculture and allied sector at the state level presents a very different picture. There has been visible shifts in the distribution of operational holdings, small and marginal farmers have increased their share. The sheer increasing number of farms pushes up the cost of delivery of the services, thereby increasing the cost of production, impacting the income from farms.
Higher credit intensive states with higher number of villages, borrowing members of co-operatives, higher amount of commercial and co-operative banks deposits, credit deposit ratio of commercial banks as per utilization, infrastructure development fund sanction, infrastructure development fund disbursement, non-performing assets of commercial banks and state domestic product were distinguished from the low credit intensive states.

Intensive focus on the eastern and north-eastern regions of the country, ushering in an "evergreen revolution", and a "rainbow revolution," agricultural marketing reforms, creating efficient agrivalue chains, promoting food/ agro processing industry, adequate and timely provision of agricultural credit will help in reducing the imbalance towards obtaining institutional credit for agriculture and coverage of farmers under an efficient crop insurance scheme.

\section{References:}

1. NABARD Annual Report (2016-17)

2. Crisil Research Agriculture Report (2016)

3. Kanhu Charan Badatya (2016), Indian Agriculture and Agri-Finance: Some Issues, pg 8 to 20

4. RBI, Database on Indian Economy

5. EPW Research Foundation (2007-08), Agricultural credit in India Changing Profile and Regional Imbalances, pg 200-208.

6. RP Misra, KV Sundaram, R Prakasa (1974), Regional Disparities, Regional Planning \& Development Strategies in India. 